\title{
The thermal behavior of a novel wall radiator panel coupled with horizontal ground source heat pump heating system: improve indoor environment to reduce the airborne transmission of infectious diseases
}

\author{
Sabrin Korichi ${ }^{1, *}$, Bachir Bouchekima ${ }^{1}$, Nabiha Naili ${ }^{2}$, and Messaouda Azzouzi ${ }^{3}$ \\ ${ }^{1}$ Laboratory of New and Renewable Energies in Arid and Saharan Areas-LENREZA, University of Kasdi Merbah-Ouargla Po \\ Box 511, Ouargla 30000, Algeria \\ ${ }^{2}$ Laboratory of Thermal Processes, Research and Technology Center of Energy, Hammam Lif, B.P. 95, Tunis 2050, Tunisia \\ (CRTEn) \\ 3 Department of Electrical Engineering, Faculty of Science and Technology, University Ziane Achour of Djelfa, Djelfa 17000, \\ Algeria
}

Received: 16 November 2020 / Accepted: 24 November 2020

\begin{abstract}
Motivated by the rapid spread of the novel pandemic disease (COVID-19) that swept the most countries in the world, a new radiation heating system consists of wall radiator panel system connected to a reversible geothermal heat pump (GHP) coupled with horizontal ground heat exchanger (HGHX) was proposed as fast and permanent solution to the risks of the dispersion of airborne infectious diseases in airconditioned enclosed spaces. An experimental system was installed and tested in the laboratory of thermal process of Research and Technology Center of Energy (CRTEn), Tunisia, in order to achieve the two main goals of this work: developing a new radiation heating system with quick and inexpensive implementation while ensuring high efficiency and environment-friendly performance for the entire system. The results obtained show that it is feasible to use the novel RPHs as heat rejecter of the horizontal ground source heat pump system (HGSHPs) for heating buildings with limited surface land areas epically those located in the Mediterranean regions such as Tunisia, the average performance coefficients of the geothermal heat pump $\mathrm{COP}_{\mathrm{hp}}$ and the overall system $\mathrm{COP}_{\text {sys }}$ are found to be 6.3 and 3 , respectively. The thermal comfort analysis indicates that there is only a small vertical temperature fluctuation in the test room that would not produce any negative effect on thermal comfort.
\end{abstract}

\section{Introduction}

In December 2019, an outbreak of respiratory illness was notified in China, it was later proven that the new disease which first appeared in Wuhan, a city in Hubei Province, was caused by a novel Coronavirus, officially called Coronavirus Disease 2019 (COVID-19) [1]. COVID-19 has rapidly spread in China and to multiple countries to reaching more than 21 million confirmed cases in less than 9 months [2].

The laboratory-confirmed cases count was markedly increased daily, which has led to conduct many studies focusing on the routes of transmission for this pandemic

\footnotetext{
* e-mail: sabrinskemr@gmail.com
}

disease. Since the enclosed spaces are the main environments in which peoples and patients spend most of their time, the majority of research focuses on the routes of spreading Coronavirus in the indoor environments [3-6]. It is reported that the recirculation of indoor air by mechanical means such as heating, ventilating and airconditioning (HVAC) systems can be largely transport the novel Coronavirus from one space and distribute them to other spaces connected to the same system by increasing the rate of air flow that carrying the airborne particles of the virus $[7,8]$.

To reduce the potential airborne transmission of this pandemic disease and any other airborne micro droplets containing viruses in enclosed spaces, especially public buildings which are used randomly (i.e. hospitals, restaurants, offices, schools, libraries, conference rooms and 
others), several engineering controls were recommended such as avoiding the air recirculation by air-conditioning (HVAC) systems and providing the outdoor air by natural ventilation process $[8,9]$.

Note that many confined hospital spaces including some residential buildings cannot naturally ventilated through airflow passages (i.e. windows and doors), In addition, the natural ventilation is not appropriate for changing climate in several regions around the world where the air-conditioning is necessary especially in heating season where the most of transmission occurs. Therefore, it is critical to highlights the use of new technique that works permanently in all circumstances and suit with all technical and economic including the environment aspects, which can replace traditional HVAC systems, in order to prevent COVID-19 airborne transmission to healthcare workers, hospital patients, environmental services, residents and others.

The thermally activated building system (TABs) is one of the most efficient distribution systems that can be improve indoor climate with lower air speeds based on different energy sources [10,11], it consists of heat exchangers which meet the heating/cooling demands of the buildings by conducts heat to/from the thermal mass of building in form of radiation, which mean that the TABs reduces the dispersion of aerosol particles and gaseous pollutants to the minimum in the indoor environments [12].

These types of low enthalpy systems can be generally classified into two types: directly activated building system (DABs), such as coil unit, radiant wall panel and radiators panel that placed in building structures; and indirectly activated building system (IABs), such as radiant floor, chilled ceiling and wall active layer that embedded into building surfaces. As mentioned, since the public places and certain types of residential rooms are characterized by intermittent random usage, the DABs that allow fast conditioning are commonly the most appropriate option, and since we focus in this study on buildings with limited land surface areas such as rooms used for critical care and residential rooms, the radiators panel heating system (RPHs) which usually occupy small spaces is particularly more suitable by increasing the heat exchange surfaces through the pipe coils [13].

The RPHs provide the desired thermal comfort conditions in the indoor environment without the need for ventilation processes by the direct radiation or convection heat transfer with the indoor air, these characteristics gives a combination of technical, economic and comfort advantages. First, the RPHs can be installed anywhere on the roofs and walls, mounted more easily, occupied a smaller area, and its shape can be easily modified so that it does not affect the appearance of the building. Second, the RPHs is usually cheaper than other TABs heat exchangers and it has a long operation life with nearly no maintenance [13]. Third, the RPHs has short thermal response time [14,15]. Fourth, there is no fan or rotating part inside the RPHs which lead to improve indoor air quality with no noise [16]. Fifth, air-conditioning with RPHs could effectively ensure the indoor thermal comfort with a reasonable indoor vertical temperature gradient
$[17,18]$. Finally, due to low supply water temperature going into the building $\left(45 / 35^{\circ} \mathrm{C}\right)$, the RPHs has a relatively higher performance and require less energy than conventional air-conditioning systems. In fact, because the RPHs require low consumption costs compared with conventional heating systems, a combination of RPHs with heat pump systems is suitable [19-21].

The geothermal heat pump called also the ground source heat pump system (GSHPs) is one of the promising applications in the renewable energy that can be provide heating or cooling to the buildings by numerous clean and safe techniques such as the horizontal ground source heat pump (HGSHP) and the vertical ground source heat pump (VGSHP). Considering the first investment costs and the geological constraints for applying the VGSHPs, the HGSHPs are usually the best option in our case.

Despite many researches which deal with both RPHs and GSHP, there are few examples that integrate both RPHs and HGSHPs, and the most research has been done in simulations laboratory tests. From literature review, Experimental study on the radiator panels as heat rejecter of HGSHPs for buildings heating still does not exist. Consequently, testing of HGSHPs with RPHs under real outdoor conditions still required for further development to pre-investigate the effectiveness of the whole system for heating spaces with selected conditions.

In this context, the main aim of this paper was to evaluate the thermal performance of wall radiator panel heating system coupled with horizontal ground source heat pump used for heating test room with limited floor area in North Tunisia. The experiment was carried out at the Research and Technology Center of Energy (CRTEn), Bordj-sédria. The experimental set-up consists of ground source heat pump coupled with horizontal ground heat exchanger implanted in $1 \mathrm{~m}$ of depth used for heating building unit equipped with capillary mat system using as heat radiator. The experimental results obtained during relatively cold days prove that the novel wall radiator panel heating system matches well with the HGSHP system, and can effectively improve the indoor thermal environment. Energy consumption is lowered through the use of free energy from the ground, and the performance coefficient of the whole system simultaneously increases.

\section{Climate of the test region}

The experimental system were installed and tested in the Thermal Processes Laboratory (LPT) at Research and Technology Center of Energy (CRTEn), Bordj-sedria. The city of Bordj-sédria is situated in the northern Tunisia in the middle of North Africa's Mediterranean coast, it is located at $36^{\circ} \mathrm{N}$ latitude and $10^{\circ} \mathrm{E}$ longitude. The northern region has a Mediterranean climate which is characterised by mild, rainy winters and hot, dry summers. The average, minimum and maximum monthly variation of temperatures, including the average monthly variation of the wind speed and insulation measured with meteorological weather station installed in the CRTEn, Borj Cédria, were displayed in Figure 1 [22,23]. 


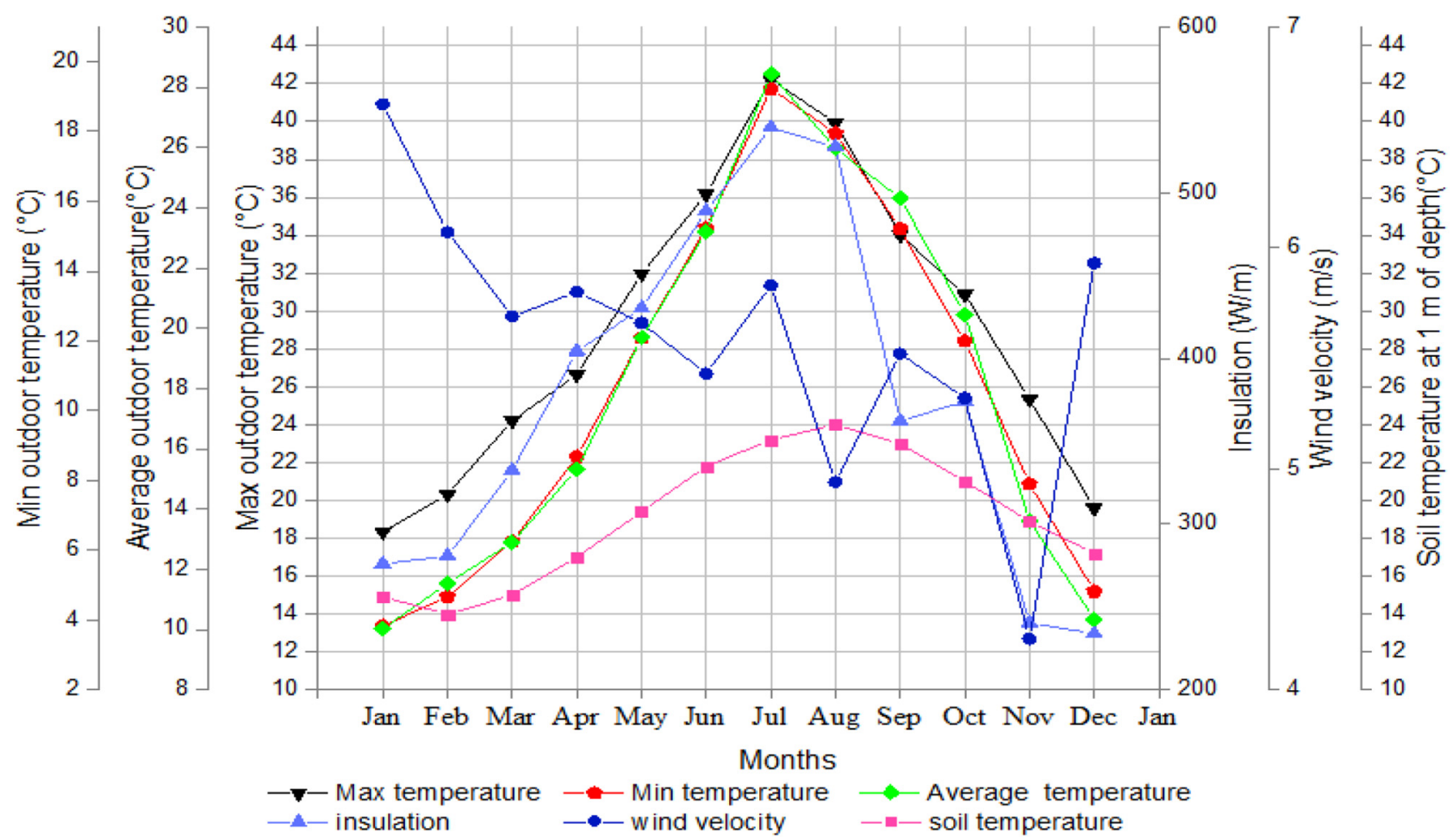

Fig. 1. Weather and geological data for Bordj Cédria city.

The study region in this work is one of the main geothermal areas in Tunisia, it has very important geothermal resources, as shown in Figure 2 [23], Bordj sédria is also characterized by a relatively low production depth (the depth in where the temperature is $40{ }^{\circ} \mathrm{C}$ above the ground surface temperature) which is located between 1000 and $1500 \mathrm{~m}$.

\section{Basics of the design}

\subsection{Analysis of energy from the ground}

Using the first law of thermodynamics, the heat transferred from the ground $\left(Q_{g}\right)$ can be computed from the following equation:

$$
Q_{g}=\dot{m}_{w-G H X} C_{p-w}\left(T_{\text {out }-G H X}-T_{\mathrm{in}-G H X}\right)
$$

\subsection{Analysis of energy to the building}

The amount of heat injected into building $\left(Q_{b}\right)$ was calculated from:

$$
Q_{b}=\dot{m}_{w-R P H s} C_{p-w}\left(T_{\text {in }-R P H s}-T_{\text {out }-R P H s}\right)
$$

$Q_{b}$ can be formulated also by the following equation:

$$
Q_{b}=U_{R P H s} S_{R P H s} L M T D
$$

where LMTD represents the log mean temperature difference, written as:

$$
L M T D=\frac{\left(T_{\mathrm{in}-R P H s}-T_{\mathrm{out}-R P H s}\right)}{\ln \frac{\left(T_{\mathrm{in}-R P H s}-T_{a m b}\right)}{\left(T_{\mathrm{out}-R P H s}-T_{\text {amb }}\right)}}
$$

Thus, the required total area of the radiator, $S_{R P H s}$ $\left(\mathrm{m}^{2}\right)$, is obtained as follows:

$$
S_{R P H s}=\frac{\dot{m}_{w-R P H s} C_{p-w}}{U_{R P H s}} \ln \frac{\left(T_{\mathrm{in}-R P H s}-T_{a m b}\right)}{\left(T_{\text {out }-R P H s}-T_{a m b}\right)}
$$

Where $\boldsymbol{U}_{\boldsymbol{R P H} \boldsymbol{s}}$ is the overall heat transfer coefficient.

\subsection{System energy efficiency}

The coefficient of performance of the heat pump $\left(\mathrm{COP}_{\mathrm{hp}}\right)$ can be estimated by the ratio between the heat injected into building and the compressor power input:

$$
\mathrm{COP}_{\mathrm{hp}}=\frac{Q_{b}}{\dot{W}_{\mathrm{Comp}}}
$$

The coefficient of performance of the overall heating system $\left(\mathrm{COP}_{\mathrm{sys}}\right)$, is calculated from the following equation:

$$
\mathrm{COP}_{\text {sys }}=\frac{Q_{b}}{\dot{W}_{\mathrm{Comp}}+\dot{W}_{\mathrm{pump}}}
$$




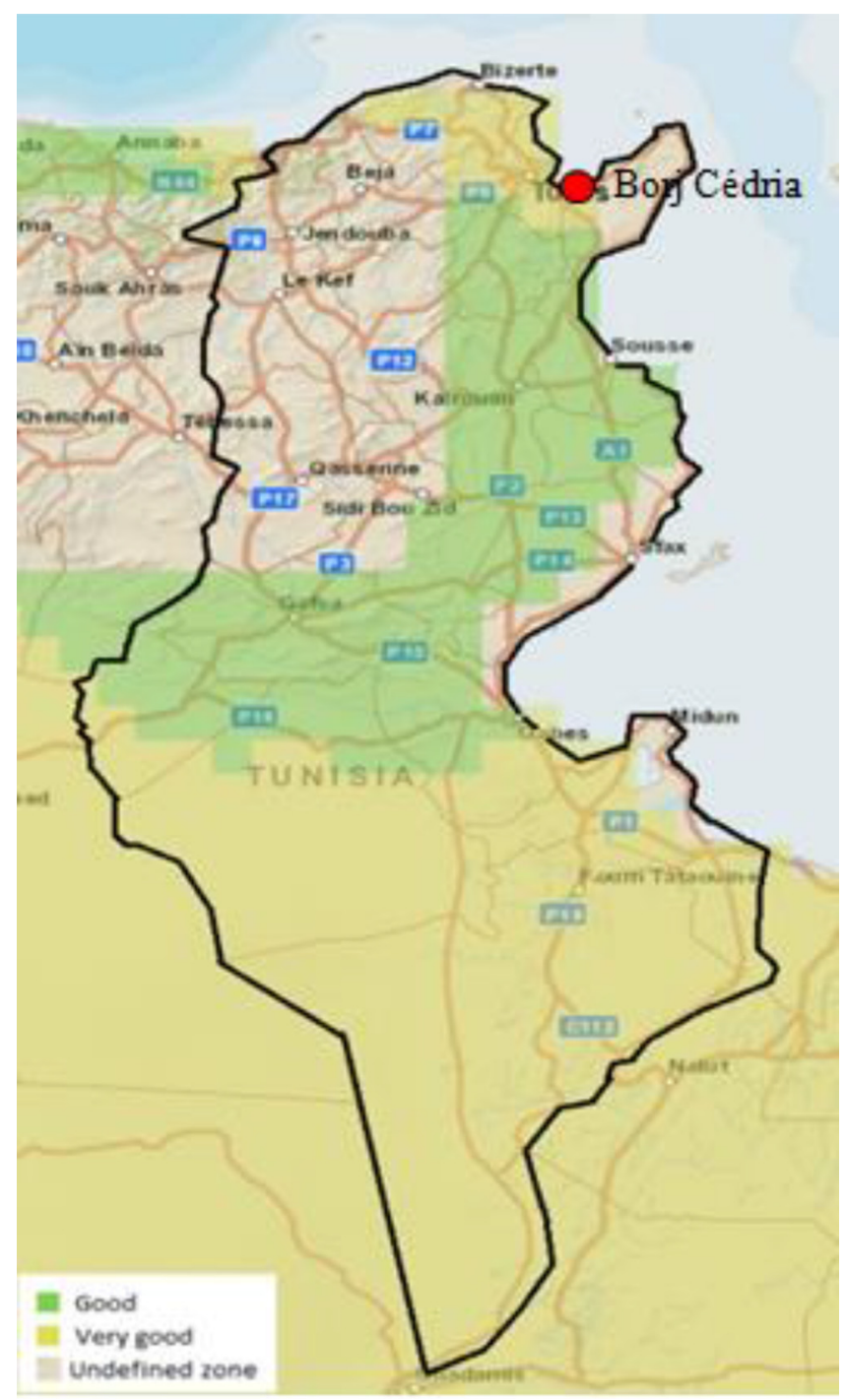

Fig. 2. The main geothermal areas in Tunisia [23].

Where $\dot{W}_{\text {Comp }}$ and $\dot{W}_{\text {pump }}$ is the electricity consumption of the compressor and the circulation pump, respectively. $\dot{W}_{\text {pump }}$ was defined as:

$$
\dot{W}_{\text {pump }}=\frac{\dot{m}_{w-G H X} H_{\text {pump }}}{\rho_{w} \eta_{\text {pump }}}
$$

where $H_{\text {pump }}$ is the total pumping head in the HGHX $\left(\Delta p_{G H X}\right)$ and heat pump $\left(\Delta p_{G H P}\right)$.

\section{Methods and materials}

\subsection{Test details}

As stated in Section 1, the experimental campaign in this work was focused on evaluating the possibility of application or replacement of conventional heating systems with low-temperature radiation heating system coupled with renewable energy source. The experiments were conducted in Mediterranean climate between 24th and 27th January 2020 in order to evaluate the thermal behavior of wall radiator panel system coupled with HGSHPs for heating load dominated building with limited floor area. The following assumptions have been made:

- The required total area of the radiator has been calculated according to the building heating loads using equation (5), (see Sect. 3.2).

- The GHX length was selected so that the installation does not excessively affect the soil thermal balance in the long run. An analysis of the influence of ground heat exchanger parameters in the studied conditions was performed in [24].

- The compressor switches on/off according to the controlled water tank temperature.

- The internal circulation pump is continuously switched on during the heating period.

- The external circulation pump switches on one minute before the compressor, and switches off $1 \mathrm{~min}$ later.

\subsection{Experimental set-up}

The experimental system consists of five components (Fig. 3): ground heat pump, horizontal ground heat exchanger, test office, radiator panel heating system and storage tank.

- North facing office room (Fig. 4), with a floor area of 12 $\mathrm{m}^{2}$ and an internal height of about $3 \mathrm{~m}$.

- The geothermal heat pump unit is a reversible water-towater, Ageo CIAT (Fig. 5a). It is equipped with two circulating pumps to circulate water in the internal and external systems. The technical properties of GHP are shown in Table 1.

- The horizontal ground heat exchanger which installed in $1 \mathrm{~m}$ of depth in the ground, is consists of a high-density polyethylene tube (HDPE) with $100 \mathrm{~m}$ of length (Fig. 5b), their technical properties are regrouped in Table 2.

- The radiator panel heating system (Fig. 5d) consists of a multilayer heat exchanger (CM heat exchanger) installed vertically in the western wall of the test office. The techanical properties of the $\mathrm{CM}$ heat exchanger are shown in Table 3.

- Insulated water tank of $0.1 \mathrm{~m}^{3}$ was integrated between the heat pump unit and the radiator panel to increase the thermal inertia of the system.

\subsection{Measurement equipment}

During the test procedures all the measurement sensors were connected to a multichannel digital Agilent type HP (Fig. 5c), which was linked to a Microsoft software program that stock the results every $1 \mathrm{~min}$ 


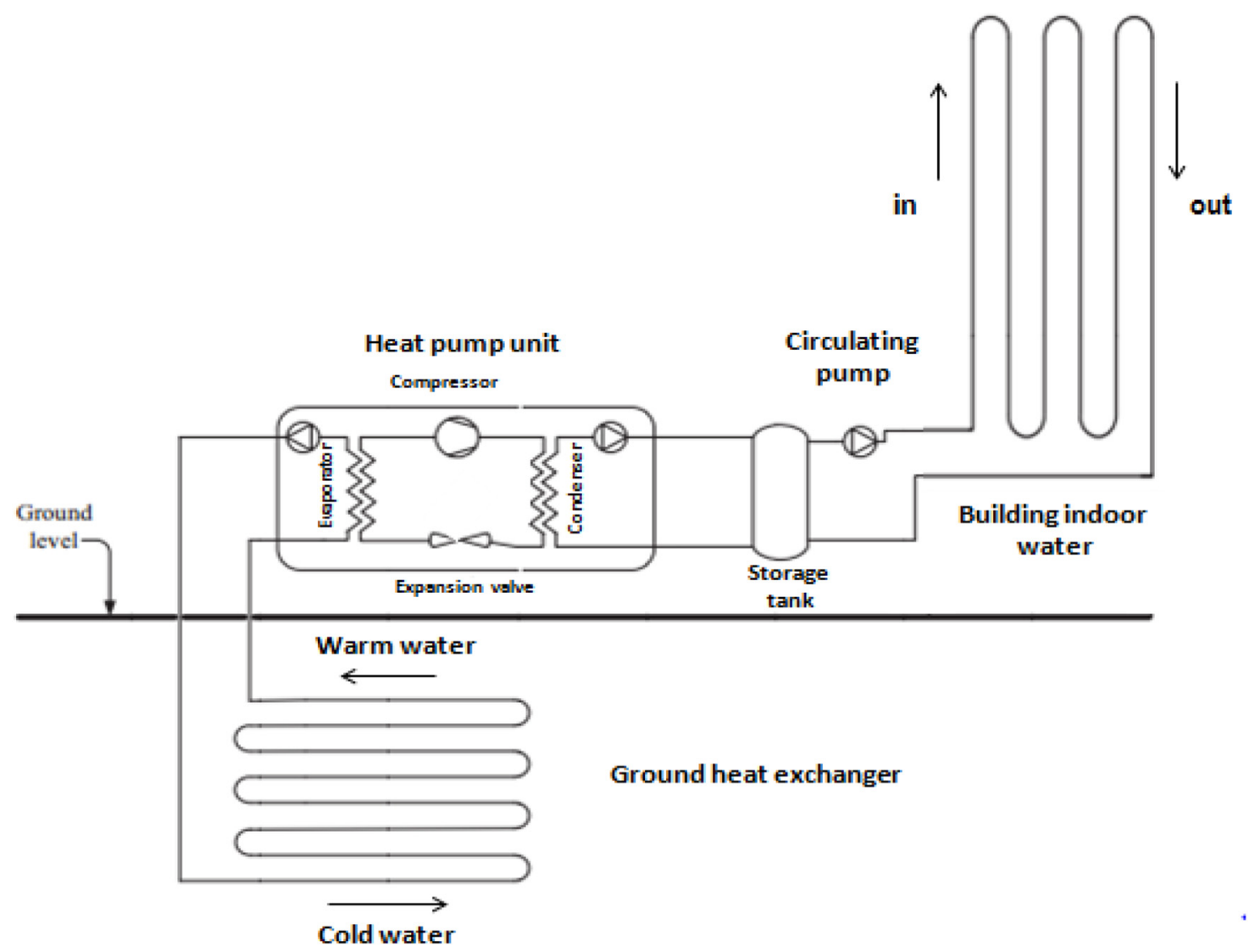

Fig. 3. Schematic diagram of the HGSHP experimental system.

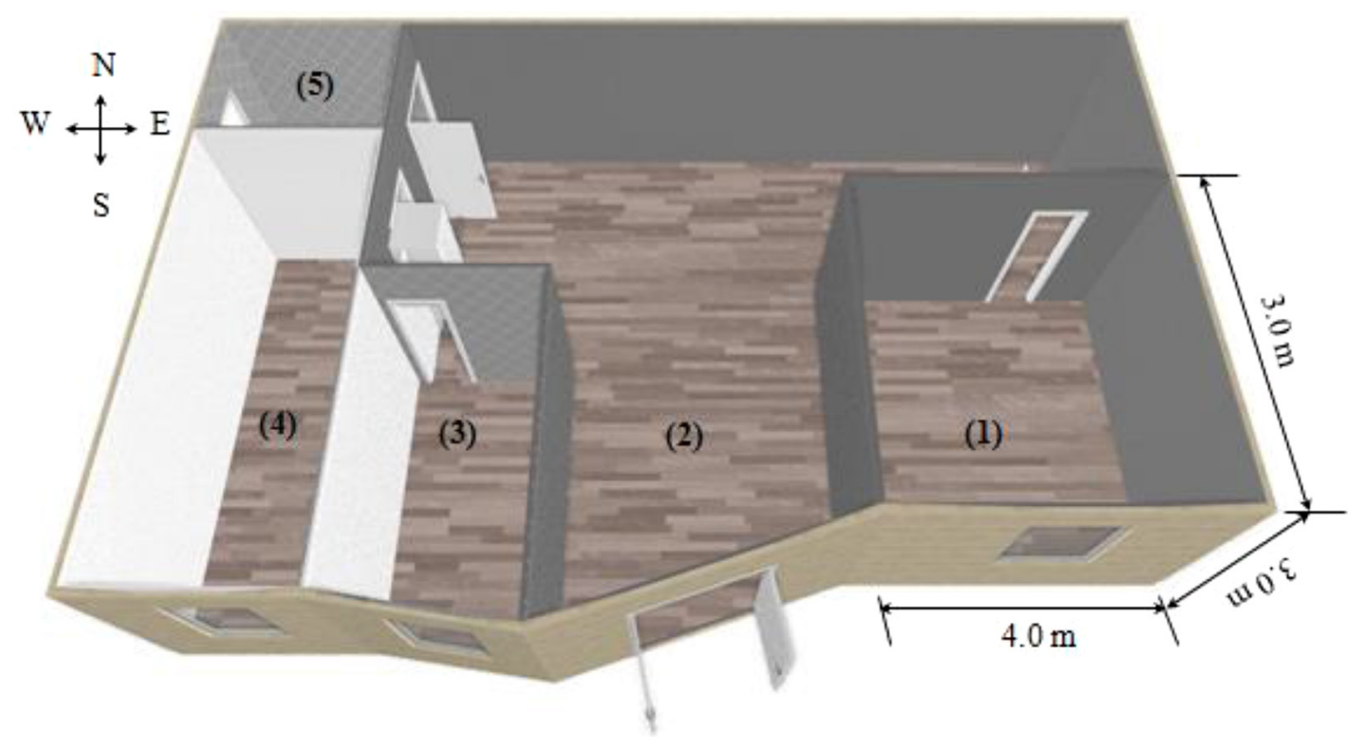

Fig. 4. 3D plan of the measurements side of thermal processes laboratory (1): Test room, (2): Test rig, (3) and (4): Office and (5): Bathroom.

during 3 days (24 January until 27 January 2020) to record any unexpected thermal behavior for the entire system. A K-type thermocouples (accuracy $\pm 1{ }^{\circ} \mathrm{C}$ ) were used to measure the ambient temperature and the temperatures indoors at different levels in the center of the test office, 3 thermocouples (K-type) were also used to measure the surface temperature of radiator pipes at 0,3 and $6 \mathrm{~m}$ of length. For the measurement of the GHX 


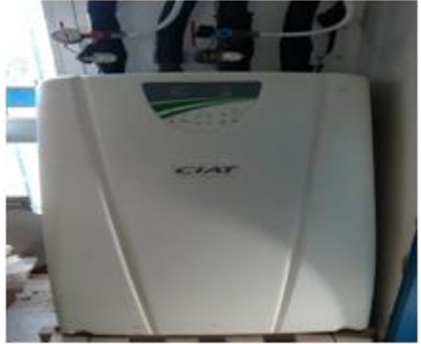

(a) The heat pump unit

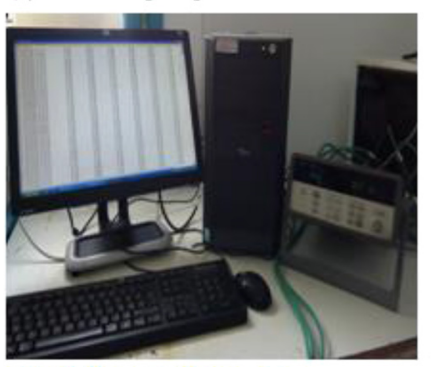

(c) The measurement system

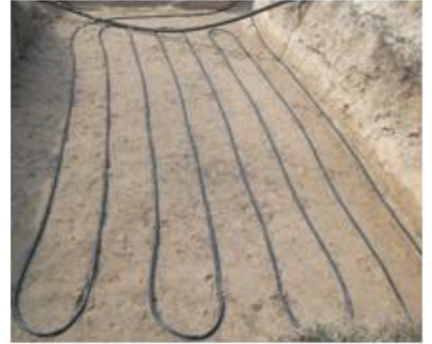

(b) The horizontal GHX

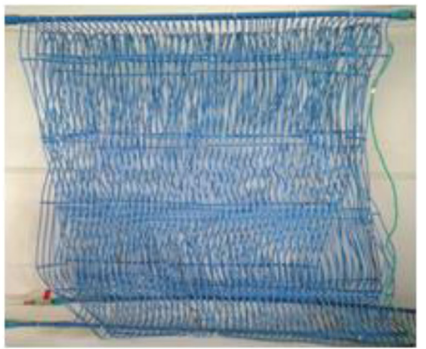

(d) The radiator heating system

Fig. 5. Views of experimental equipments and measurement system.

Table 1. Technical Specification of the reversible water to water heat pump.

\begin{tabular}{ll}
\hline Parameter & Specification \\
\hline Type & AGEO $50 \mathrm{HT}$ \\
Refrigerant & $\mathrm{R} 410 \mathrm{~A}$ \\
Heating capacity & $16.1 \mathrm{~kW}$ \\
Inlet/outlet temperature & $40.0^{\circ} \mathrm{C} / 45.0^{\circ} \mathrm{C}$ \\
Flow rate & 2.77 \\
Cooling capacity & $12.2 \mathrm{~kW}$ \\
Inlet/outlet temperature & $12.0^{\circ} \mathrm{C} / 7.0^{\circ} \mathrm{C}$ \\
Flow rate & 2.1 \\
\hline
\end{tabular}

Table 2. Technical specification of the ground heat exchanger.

\begin{tabular}{ll}
\hline Parameter & Specification \\
\hline Pipe material & High density polyethylene \\
Diameter $(\mathrm{m})$ & 0.025 \\
Thickness $(\mathrm{m})$ & 0.0023 \\
Length $(\mathrm{m})$ & 100 \\
Tube spacing $(\mathrm{m})$ & 0.5 \\
Conductivity $\left(\mathrm{W} \mathrm{m} \mathrm{K}^{-1} \mathrm{~K}^{-1}\right)$ & 0.48 \\
\hline
\end{tabular}

water temperature two wires PT500 resistance thermometer sensors (accuracy $\pm 5.71 \%$ ) were placed at the inlet and outlet of the GHX.

Table 3. Technical specification of the capillary mate heat exchanger.

\begin{tabular}{ll}
\hline Parameter & Specification \\
\hline Pipe type & $\begin{array}{l}\text { Capillary mate heat } \\
\text { exchanger }\end{array}$ \\
Diameter $(\mathrm{m})$ & 0.0034 \\
Thickness $(\mathrm{m})$ & 0.00055 \\
Length $(\mathrm{m})$ & 6 \\
Tube spacing $(\mathrm{m})$ & 0.015 \\
Conductivity $\left(\mathrm{W} \mathrm{m} \mathrm{K}^{-1}\right)$ & 0.4 \\
\hline
\end{tabular}

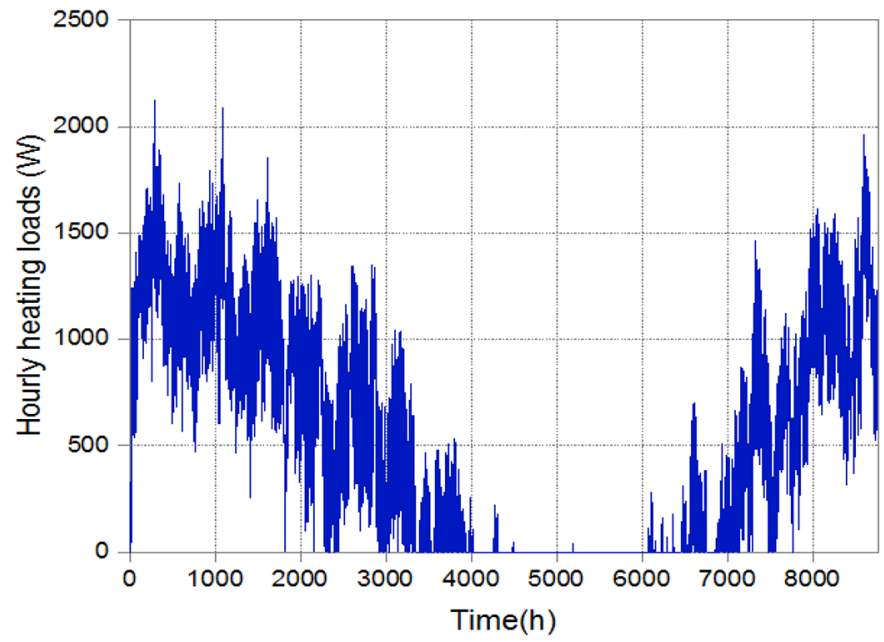

Fig. 6. The hourly heating loads of the test room.

\subsection{The heating loads}

In this work, the heating loads were calculated using a TRNSYS model of the climate test room, which is developed according to the construction specifications of the Thermal Process Laboratory (Fig. 4), as follows:

- The flat roof made with $20 \mathrm{~cm}$ heavy concrete block, $8 \mathrm{~cm}$ screed and $1 \mathrm{~cm}$ asphalt.

- The walls made with a double pane of $0.15 \mathrm{~m}$ hollow bricks, $0.03 \mathrm{~m}$ plaster on each side, and $0.05 \mathrm{~m}$ of air insulation layer.

- South facing window with $3 \mathrm{~m}^{2}$.

The heating thermostat was set as $23^{\circ} \mathrm{C}$ according to the thermal comfort standards in the the test region, Figure 6 represents the annual heating loads of the test office which were calculated based on the weather data of north coast climate. It is clear that the heating period lasts about 7 months, from October to April. The heating loads reach their maximum in January of about $2.12 \mathrm{~kW}$.

\section{Results and discussion}

This section analyses the performance and the feasibility of the wall radiator panel system coupled to a HGSHPs in heating mode. Experiments were conducted to find the ambient temperature, average indoor temperature, HGHX 


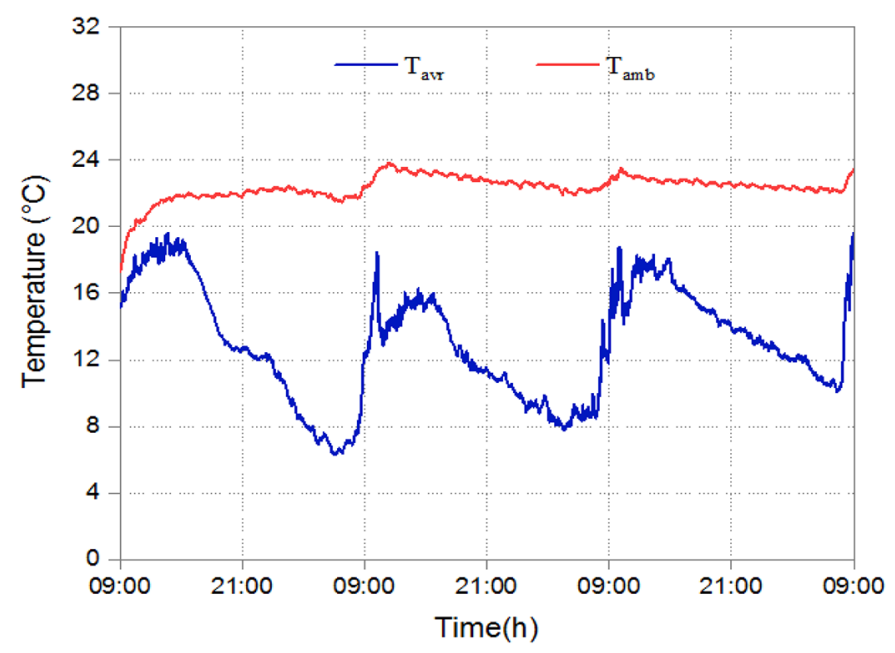

Fig. 7. Comparison between indoor and outdoor temperatures using the HGSHPs as an air conditioning system versus local time.

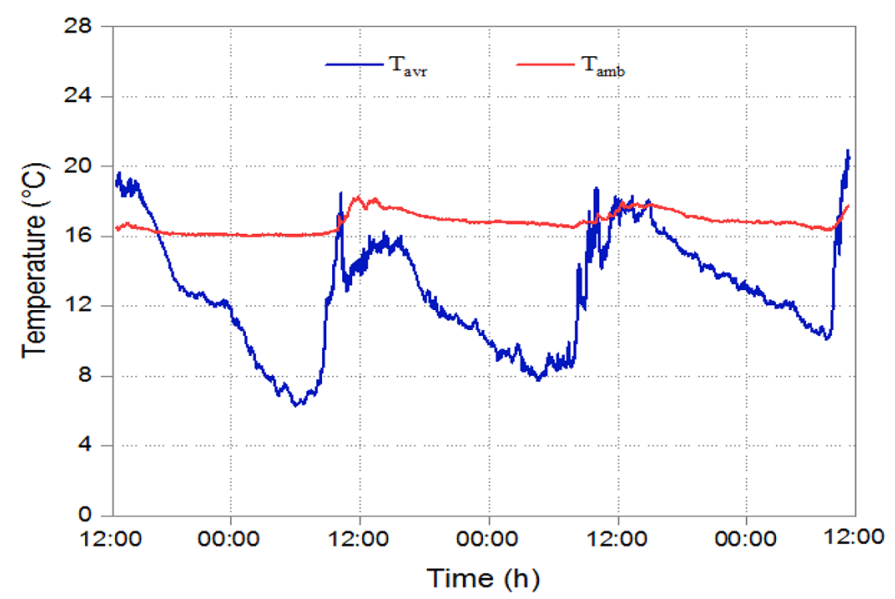

Fig. 8. Comparison between indoor and outdoor temperatures without air conditioning system versus local time.

inlet and outlet water temperature and RPHs inlet and outlet water temperature.

\subsection{The air temperature of the test office}

Figures 7 and 8 shows the hourly variation of the average indoor temperature of the test office $\left(T_{a m b}\right)$ compared with the outdoor temperature $\left(T_{\text {aver }}\right)$ with and without air conditioning system, respectively. It can be seen from this figures that the radiator panel heating system has raised the average temperature inside the test office of about $6{ }^{\circ} \mathrm{C}$ to reaches a comfortable levels at an average value of about $23{ }^{\circ} \mathrm{C}$, a slight fluctuations in the indoor temperature was noticed due to the decrease temperature in the storage tank when the compressor switch off.

\subsection{Thermal comfort analysis}

\subsubsection{The vertical difference of air temperature}

As fluctuations in room temperature between head and ankle levels and the variations in air temperature with time affect the human thermal comfort [25], an assessment of the vertical difference of air temperature throughout the heating period was carried out. Figure 9 shows the variation of the indoor temperature at different altitudes (L1: floor, L2: $1.4 \mathrm{~m}$ above floor, L3: roof, as shown in Fig. 10). Results illustrate that after the activation of the GHP system at 9:00 am the radiator heating system raises the air temperatures inside the test office by $4-8{ }^{\circ} \mathrm{C}$ compared with its values at the beginning of the heating period. The average indoor air temperature increases gradually to reaches $23.5,23$ and $22.4{ }^{\circ} \mathrm{C}$ at the different levels L1, L2 and L3, respectively. Slight fluctuations in the indoor air temperature between head and ankle levels of about $\pm 1{ }^{\circ} \mathrm{C}$ from its desired value ( 7 in Tab. 4) were observed at midday due to variations in the outdoor air temperature and solar heat gains. The time duration to produce these temperature changes is about $4 \mathrm{~h}$, which will not cause any thermal discomfort.

\subsubsection{Floor surface temperature}

Contact with floor surfaces that are too warm or too cool may cause thermal discomfort for foot. In general, people wear shoes or walk on carpets or floor covering, however this section is proposed for people wearing lightweight indoor shoes. The hourly variation of the floor surface temperature during the testing period was given also in Figure 9. After the thermal stabilization at 12:00 am, the floor surface temperature varies from 19 to $21.2{ }^{\circ} \mathrm{C}$ and the mean value is $20.4{ }^{\circ} \mathrm{C}$ during the testing period. According to the prescribed limits set in ASHRAE 55-2004 standards that depicted in Table 4, the floor surface temperature in the investigated room is within the normal range.

\subsection{RPHs inlet and outlet water temperature}

Figure 11 shows the periodically variation of the inlet and outlet water temperature in the radiator panel heating system. We can note from this figure that the outlet and the inlet RPHs temperatures increases gradually at the beginning of the heating period to reaches its maximum at 12:40 am, after that the inlet water temperature ranged from 36 to $40^{\circ} \mathrm{C}$ and the outlet temperature varied from 32 to $34^{\circ} \mathrm{C}$.

The differences between the $T_{\mathrm{out}-R P H s}$ and $T_{\mathrm{in}-R P H s}$ was translated to an amount of heat rejected into the building $\left(Q_{b}\right)$ using equation (2) (7 in Fig. 12). It was found that the amount of heat rejected into building reaches a maximum value of about $1.9 \mathrm{~kW}$ at the beginning of the GHP operation due to the high heating loads of the test office, and then the heat injected decreases gradually after $1 \mathrm{~h}$ of GHP operation, its values vary between 0.8 and $1.4 \mathrm{~kW}$. This variation can be justified by the intermittent operation of the compressor.

\subsection{The radiator heating system response}

To determine the heating system time response, the surface temperature of the RPHs was collected at different distances (D1: 0 m, D2: $3 \mathrm{~m}$, D3: $6 \mathrm{~m}$ ) during the GHP operation period. Figure 13 shows that after the activation 

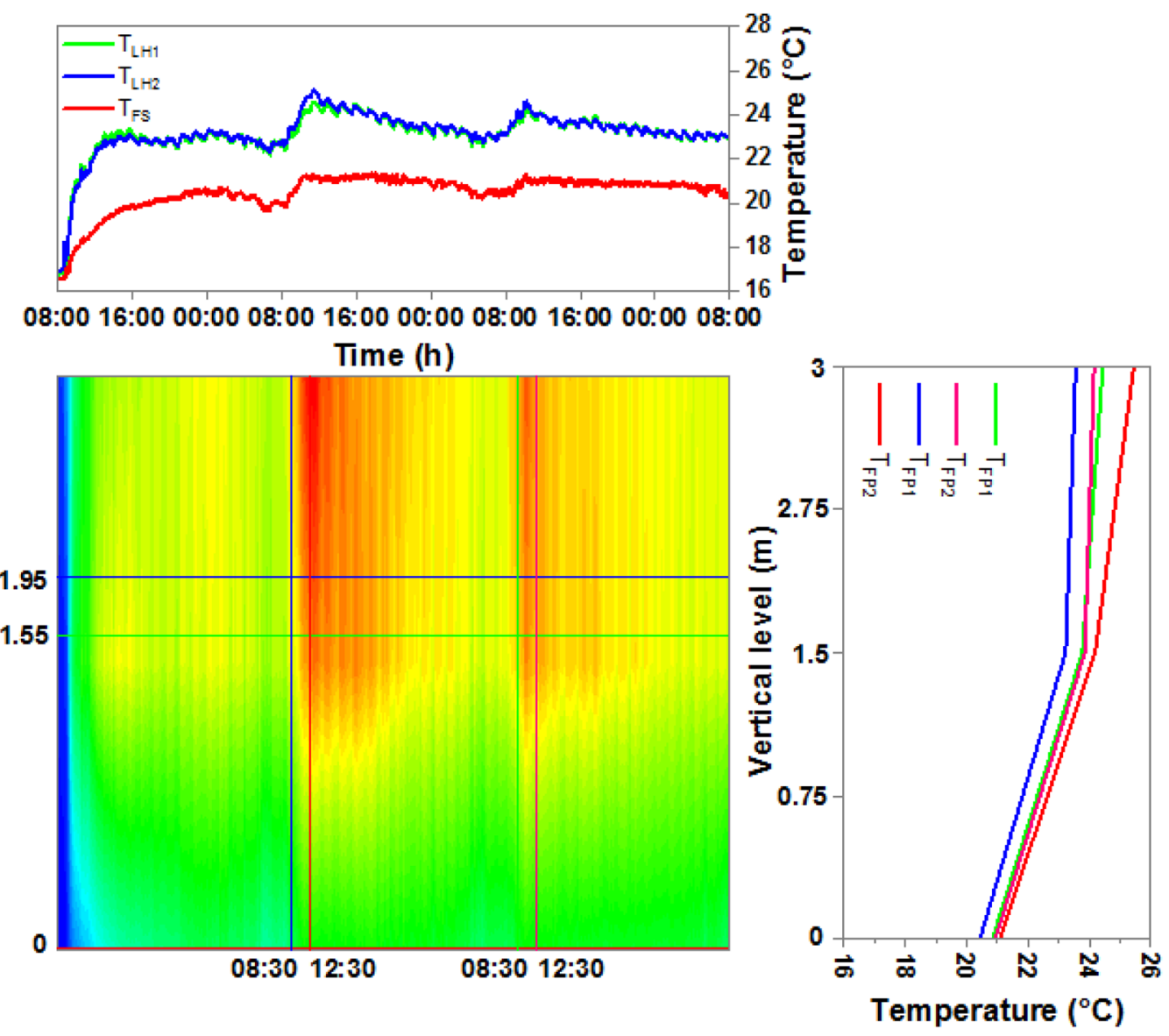

Fig. 9. Evolution of room temperature at different levels versus local time.

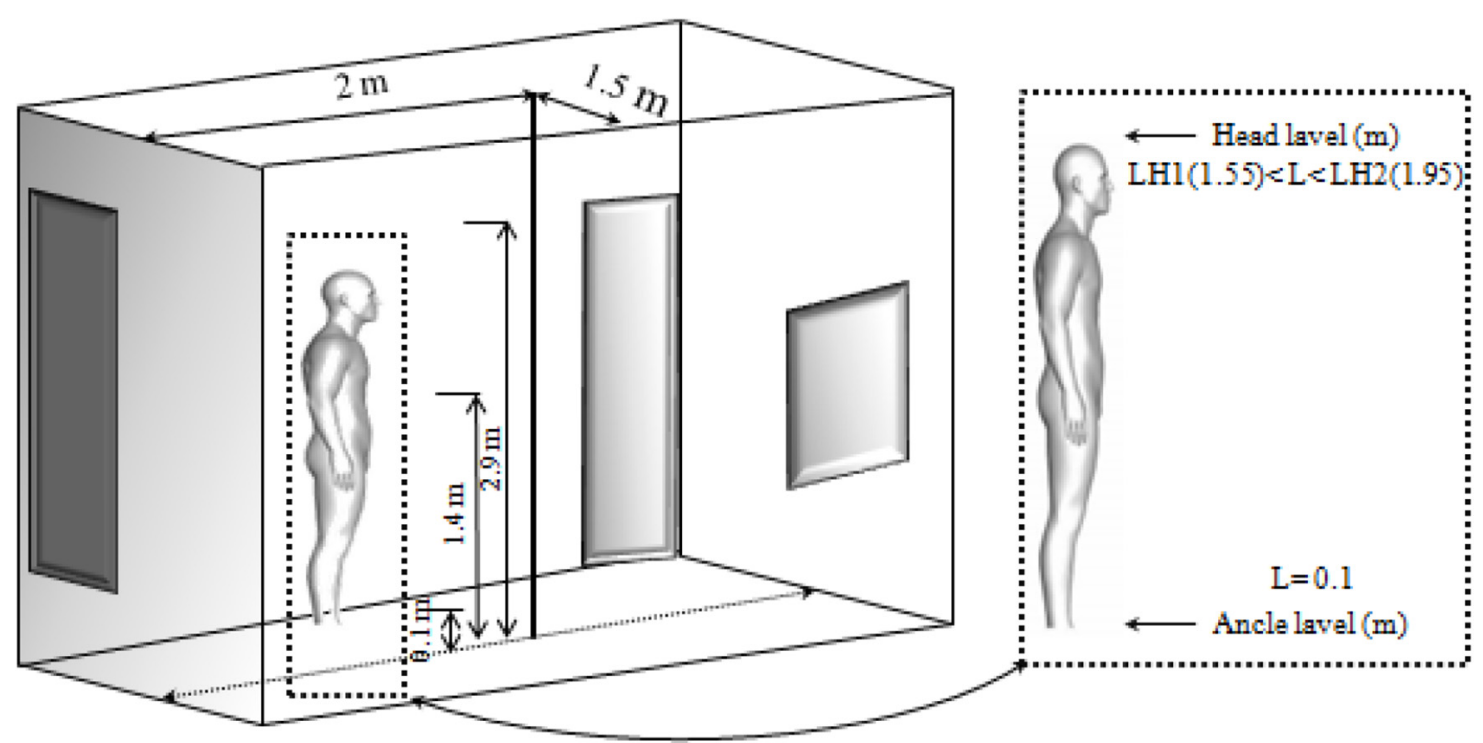

Fig. 10. Temperature measurements points in the test room. The black surface represents the radiator's heating area.

Table 4. The classification of indoor comfort proposed by ASHREA [25].

\begin{tabular}{lc}
\hline Parameter & Allowable range \\
\hline Vertical air temperature difference between head and ankles & $<3{ }^{\circ} \mathrm{C}$ \\
Range of surface temperature of the floor & $19-29{ }^{\circ} \mathrm{C}$ \\
\hline
\end{tabular}




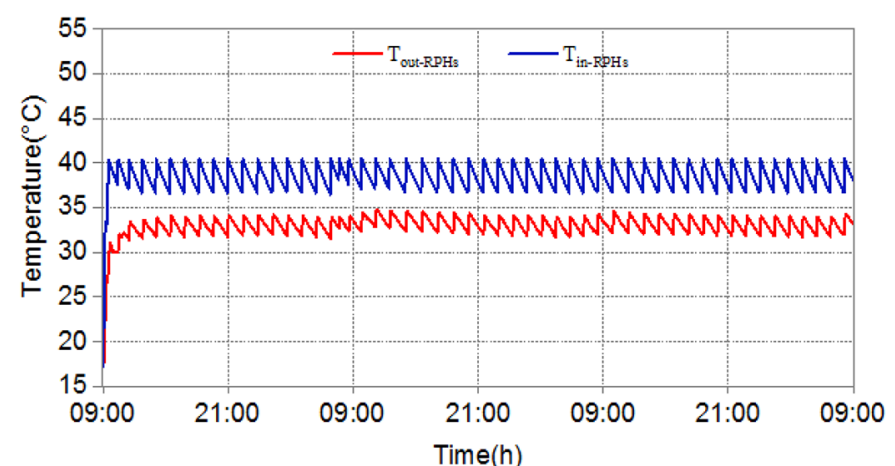

Fig. 11. Evolution of water temperatures at the internal circuit versus local time.

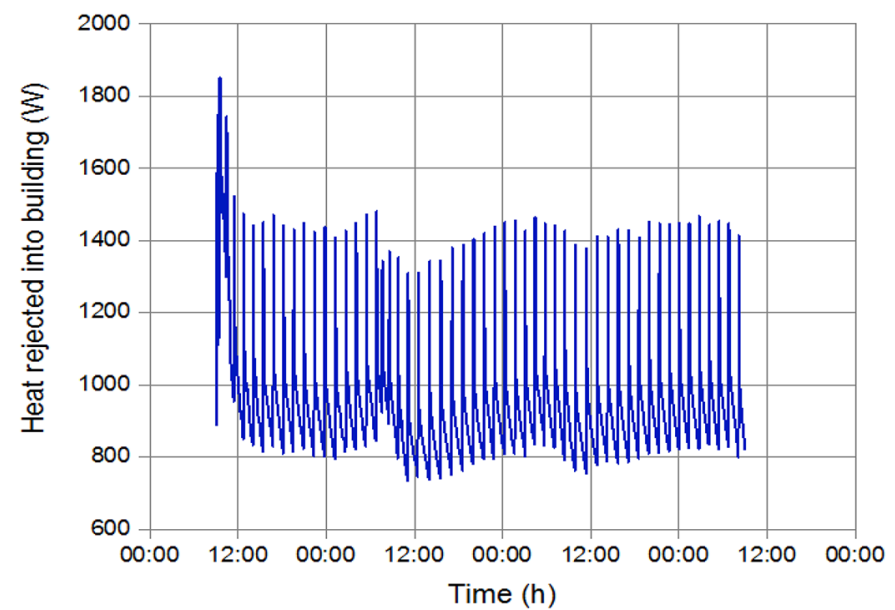

Fig. 12. Evolution of the heat rejected into building.

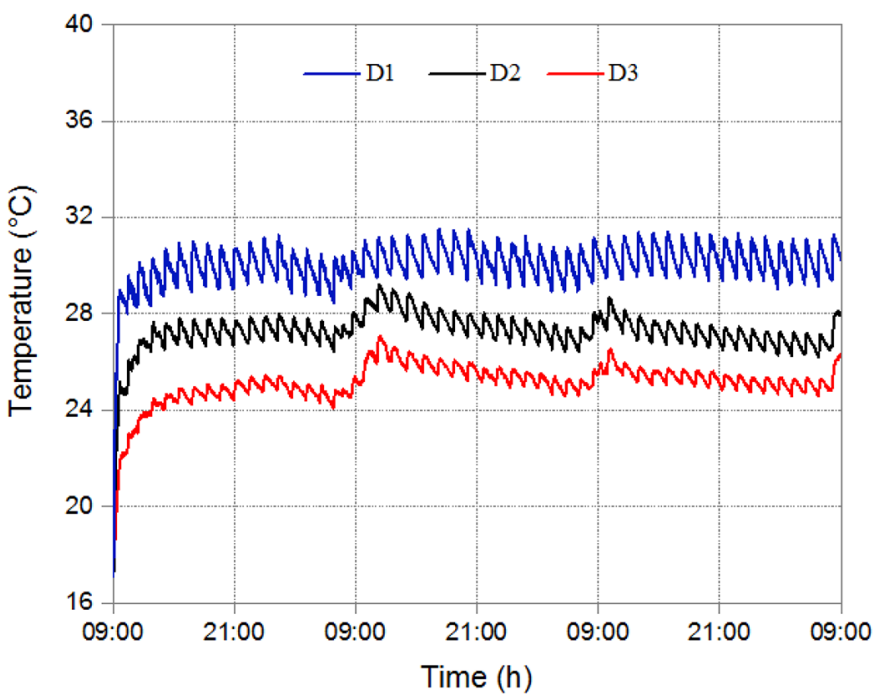

Fig. 13. Evolution of heat pipes radiator surface temperature distribution versus local time.

of the GSHP system at 9:00 am, the RPHs surface temperature increases gradually until average values of about $30,27,25^{\circ} \mathrm{C}$ at D1, D2, D3, respectively. The system

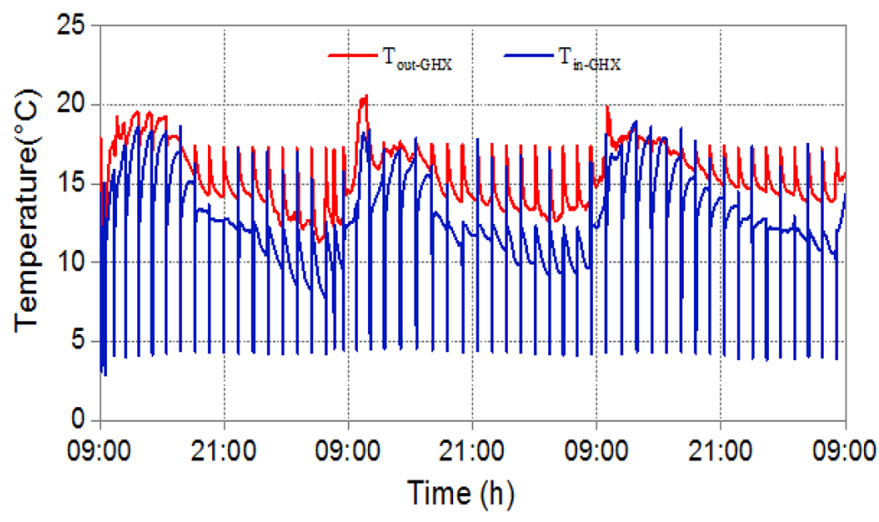

Fig. 14. Evolution of water temperatures at the external circuit versus local time.

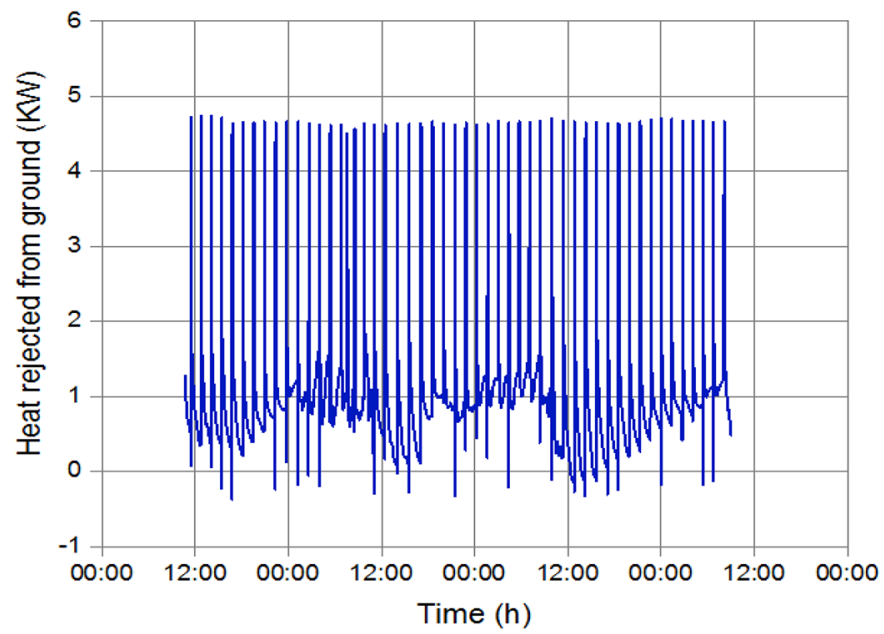

Fig. 15. Evolution of the heat rejected from ground.

has stabilized at these temperature levels in a short period of about $30 \mathrm{~min}$, which indicates the rapidity response of the radiator panel heating system.

\subsection{HGHX inlet and outlet water temperature}

In order to evaluate the thermal capacity of the ground, the variation of the inlet and outlet ground heat exchanger temperatures were represented in Figure 14. The results shows that the outlet temperature reaches a maximum value of about $20^{\circ} \mathrm{C}$ when the compressor switches on and reaches a minimum value of about $12{ }^{\circ} \mathrm{C}$ when the compressor switches off, this corresponds to the change in the inlet temperature varies between 4 and $18^{\circ} \mathrm{C}$. Figure 15 presents the heat transferred from the ground calculated using equation (1), it is varies from 4.4 to $4.5 \mathrm{~kW}$ when the compressor switches on. This result can be explained by the high thermal response of the ground in the test region.

\subsection{Overall performance}

To understand the effect of the thermal behavior of the RPHs on the performance of the HGHP system, the 
Table 5. Comparison of this study with other investigations.

\begin{tabular}{|c|c|c|c|c|}
\hline Research & Region & Technical specification & $\begin{array}{l}\text { Outdoor } \\
\text { temperature } \\
\left({ }^{\circ} \mathrm{C}\right)\end{array}$ & $\begin{array}{l}\text { The coefficient } \\
\text { of performance } \\
\text { (COP) }\end{array}$ \\
\hline Present work & Tunisia & Wall radiator panel with HGSHP & $6.27-20.91$ & $6.19-6.47$ \\
\hline Shao et al. [16] & China & Refrigerant-heated radiator with ASHP & $-9.2-14$ & $1.7-3.5$ \\
\hline Zhang et al. [26] & China & $\begin{array}{l}\text { Thermal storage refrigerant- } \\
\text { heated radiator with ASHP }\end{array}$ & $-18.4-6.9$ & $1.8-4.2$ \\
\hline $\mathrm{Xu}$ et al. [14] & China & Heat pipes radiator with ASHP & $-15-0$ & $2.55-1.4$ \\
\hline
\end{tabular}

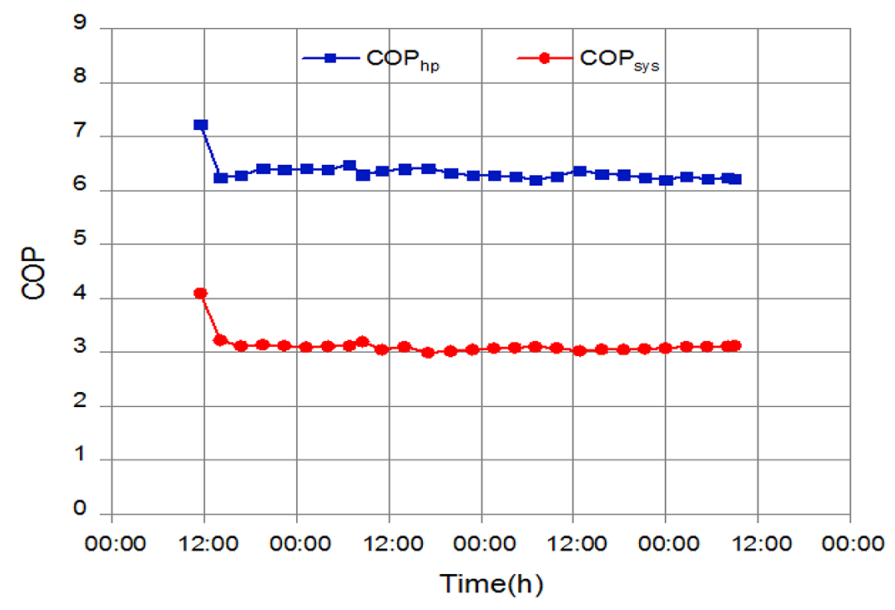

Fig. 16. Evolution of COP of the heat pump and the whole system versus locale time.

variation of the performance coefficient of the heat pump and of the whole system which were calculated using equations (6) and (7), respectively, was shown in Figure 16.

The average values of the $\mathrm{COP}_{\mathrm{hp}}$ and the $\mathrm{COP}_{\text {sys }}$ in the beginning of the heating period, were found to be 7.4 and 4.1 , respectively. After the stabilization of the system which was noticed at 14:00, these curves indicate a performance degradation of about $15 \%$ and $27 \%$ in $\mathrm{COP}_{\mathrm{hp}}$ and $\mathrm{COP}_{\text {sys }}$, respectively, the degradation can be explained by the decreases in the inlet temperature of the GHP evaporator, due to the decreases in soil temperature $\left(\boldsymbol{T}_{\boldsymbol{g}}\right)$ around the outlet of the GHX. A performance results comparison of this study with the results of other research studies is summarised in Table 5 .

\section{Conclusion}

In the present study, the thermal behavior of a novel wall radiator panel heating system connected with horizontal ground source heat pump was examined experimentally under the climatic conditions of the Mediterranean region. The whole system was proposed to provide clean heating for confined enclosed spaces, in order to minimize the airborne transmission of the infectious disease caused by the traditional air-conditioning and heating systems. The following results are observed:
- The combined radiator panel heating system is capable of maintaining the studied room within the required temperature level throughout the heating periods.

- The use of $6 \mathrm{~m}$ of capillary mat as a radiator heating system raises the air temperature inside the building unit of about $6^{\circ} \mathrm{C}$ within $2 \mathrm{~h}$ maximum, which reflects the rapidity of the system response.

- The thermal comfort analysis indicates a small vertical difference of air temperature inside the test building, which would not produce any significant thermal discomfort.

- The coefficients of the performance of the heat pump $\left(\mathrm{COP}_{\mathrm{hp}}\right)$ and the overall system $\left(\mathrm{COP}_{\text {sys }}\right)$ ranges between 6.2 to 6.4 and 2.9 to 3.1, respectively

Finally, it can be concluded that the novel radiator panel heating system is an effective solution for improve indoor climate and the coefficient of performance of the geothermal heat pump simultaneously. Therefore, we emphasize that using such clean energy-efficient heating systems in hospitals and other residential and public spaces will reduce the rates of airborne infection not only for COVID-19 in the current novel pandemic, but also for other airborne infectious diseases if it is implemented on a large scale.

\section{Nomenclature}

$\eta_{\text {pump }} \quad$ Electric efficiency of circulating pump (\%)

$\mathrm{COP}_{\mathrm{hp}} \quad$ Coefficient of performance of the heat pump

$\mathrm{COP}_{\text {sys }} \quad$ Coefficient of performance of whole system

$T_{g} \quad$ Ground temperature $\left({ }^{\circ} \mathrm{C}\right)$

$T_{\text {in-GHX }} \quad$ GHX entering water temperature $\left({ }^{\circ} \mathrm{C}\right)$

$T_{\text {in-GHX }} \quad$ GHX leaving water temperature $\left({ }^{\circ} \mathrm{C}\right)$

$\dot{m}_{w-G H X} \quad$ GHX water mass flow rate $(\mathrm{kg} / \mathrm{s})$

$\mathrm{U}$

$\mathrm{W}$

$T_{\mathrm{in}-R P H s}$

$T_{\text {out- }-R P H s}$

$\dot{m}_{w-R P H s}$

$T_{\text {avr }}$

$T_{a m b}$

$Q_{b}$

$Q_{g}$

$C_{p-w}$
Overall heat transfer coefficient $\left(\mathrm{W} / \mathrm{m}{ }^{\circ} \mathrm{C}\right)$

Power consumption (kW)

RPHs entering water temperature $\left({ }^{\circ} \mathrm{C}\right)$

RPHs leaving water temperature $\left({ }^{\circ} \mathrm{C}\right)$

RPHs water mass flow rate $(\mathrm{kg} / \mathrm{s})$

The average indoor air temperature

The ambient air temperature

The heat absorbed from the building (W)

The heat transferred to the ground (W)

The fluid specific heat of the water $(\mathrm{kJ} / \mathrm{kgK})$ 


$\begin{array}{ll}T_{F P 1} & \begin{array}{l}\text { The temperature at the beginning of the } \\ \text { fluctuation period }\left({ }^{\circ} \mathrm{C}\right)\end{array} \\ T_{F P 2} & \begin{array}{l}\text { The temperature at the end of the fluctuation } \\ \text { period }\left({ }^{\circ} \mathrm{C}\right)\end{array} \\ T_{F S} & \begin{array}{l}\text { The floor surface temperature }\left({ }^{\circ} \mathrm{C}\right) \\ H_{\text {pump }}\end{array} \\ S & \begin{array}{l}\text { The pressure drop }(\mathrm{Pa}) \\ \text { The heat transfer surface area of exchanger } \\ \left(\mathrm{m}^{2}\right)\end{array}\end{array}$

Subscripts

$\begin{array}{ll}\text { Aver } & \text { Average } \\ \text { amb } & \text { Ambient } \\ \text { b } & \text { Building } \\ \text { Pump } & \text { Circulating pump } \\ \text { g } & \text { Ground } \\ \text { RPHs } & \text { Radiator panel heating system } \\ \text { Min } & \text { Minimum } \\ \text { Max } & \text { Maximum } \\ \text { S } & \text { System } \\ \text { W } & \text { Water }\end{array}$

Abbreviation

CM Capillary mat

DABs Directly activated building system

GSHP Ground source heat pump

GHX Ground heat exchangers

GHP Ground heat pump

HGSHP Horizontal ground source heat pump

HDPE High-density polyethylene

IABs Indirectly activated building system

TABs The thermally activated building system

VGSHP Vertical ground source heat pump

The authors would like to thank the Thermal Processes Laboratory (LPT) and the Research and Technology Center of Energy (CRTEn), Tunisia for financially supporting the project, the authors would like to acknowledge Dr. Nabiha Naili for her encouragement throughout this study.

\section{References}

1. S.C. Cheng, Y.C. Chang, Y.L.F. Chiang, Y.C. Chien, M. Cheng, C.H. Yang, C.H. Huang, Y.N. Hsu, First case of Coronavirus Disease 2019 (COVID-19) pneumonia in Taiwan, J. Formos. Med. Assoc. (2020). https://doi.org/ 10.1016/j.jfma.2020.02.007

2. World Health Organization. Coronavirus disease 2019 (COVID-19) situation report-209. https://www.who.int/ docs/default-source/coronaviruse/situation-reports/20200816covid-19-sitrep-209.pdf?sfvrsn=5dde1ca2 2

3. C. Xu, X. Wei, L. Liu, L. Su, W. Liu, Y. Wang, P.V. Nielsen, Effects of personalized ventilation interventions on airborne infection risk and transmission between occupants, Build. Environ. 180, 107008 (2020)

4. M.A. Kohanski, L.J. Lo, M.S. Waring, Review of indoor aerosol generation, transport and control in the context of COVID-19, Int. Forum Allergy Rhinol. (2020). https://doi. org/10.1002/alr.2266
5. T. Jin, J. Li, J. Yang, J. Li, F. Hong, H. Long, Q. Song, SARSCoV-2 presented in the air of an intensive care unit (ICU), Sustain. Cities Soc. 102446 (2020)

6. N.A. Megahe, E.M. Ghoneim, Antivirus-built environment: lessons learned from Covid-19 pandemic, Sustain. Cities Soc. 61, 102350 (2020)

7. G. Correia, L. Rodrigues, M.G. Silva, T. Gonçalves, Airborne route and bad use of ventilation systems as non-negligible factors in SARS-CoV-2 transmission, Med. Hypotheses 109781 (2020)

8. L. Morawaska, J.W. Tang, W. Bahnfleth, P.M. Bluyssen, A. Boerstra, G. Buonanno, C. Haworth, How can airborne transmission of COVID-19 indoors be minimised? Environ. Int. (2020). https://doi.org/10.1016/j.envint.2020.105832

9. X.Y. Ge, Y. Pu, C.H. Liao, W.F. Huang, Q. Zeng, H. Zhou, H. L. Chen, Evaluation of the exposure risk of SARS-CoV-2 in different hospital environment, Sustain. Cities Soc. 61, 102413 (2020)

10. M. Bojić, D. Cvetković, L. Bojić, Decreasing energy use and influence to environment by radiant panel heating using different energy sources, Appl. Energy 138, 404-413 (2015)

11. J. Romaní, G. Pérez, A. de Gracia, Experimental evaluation of a heating radiant wall coupled to a ground source heat pump, Renew. Energy 105, 520-529 (2017)

12. V. Golkarfard, P. Talebizadeh, Numerical comparison of airborne particles deposition and dispersion in radiator and floor heating systems, Adv. Powder Technol. 25, 389-397 (2014)

13. Y. Man, H. Yang, J.D. Spitler, Z. Fang, Feasibility study on novel hybrid ground coupled heat pump system with nocturnal cooling radiator for cooling load dominated buildings, Appl. Energy 88, 4160-4171 (2011)

14. S. Xu, R Ding, J. Niu, G. Ma, Investigation of air-source heat pump using heat pipes as heat radiator, Int. J. Refrig. 90, 91-98 (2018)

15. K. Kerrigan, H. Jouhara, G.E. O'Donnell, A.J. Robinson, Heat pipe-based radiator for low grade geothermal energy conversion in domestic space heating, Simul. Model. Pract. Theory 19, 1154-1163 (2011)

16. S. Shao, H. Zhang, S. You, W. Zheng, L. Jiang, Thermal performance analysis of a new refrigerant-heated radiator coupled with air-source heat pump heating system, Appl. Energy 247, 78-88 (2019)

17. A. Hasan, J. Kurnitski, K. Jokiranta, A combined low temperature water heating system consisting of radiators and floor heating, Energy Build. 41, 470-479 (2009)

18. J.A. Myhren, S. Holmberg, Flow patterns and thermal comfort in a room with panel, floor and wall heating, Energy Build. 40, 524-536 (2008)

19. B. Kilkis, Exergy metrication of radiant panel heating and cooling with heat pumps, Energy Convers. Manag. 63, 218-224 (2012)

20. U. Akbulut, Z. Utlu, O. Kincay, Exergoenvironmental and exergoeconomic analyses of a vertical type ground source heat pump integrated wall cooling system, Appl. Therm. Eng. 102, 904-921 (2016)

21. Q. Zhang, L. Zhang, J. Nie, Y. Li, Techno-economic analysis of air source heat pump applied for space heating in Northern China, Appl. Energy 207, 533-542 (2017)

22. H. Boughanmi, M. Lazaar, S. Bouadila, A. Farhat, Thermal performance of a conic basket heat exchanger coupled to a geothermal heat pump for greenhouse cooling under Tunisian climate, Energy Build. 104, 87-96 (2015) 
23. N. Naili, M. Hazami, I. Attar, A. Farhat, Assessment of surface geothermal energy for air conditioning in northern Tunisia: direct test and deployment of ground source heat pump system, Energy Build. 111, 207-217 (2016)

24. N. Naili, M. Hazami, I. Attar, A. Farhat, In-field performance analysis of ground source cooling system with horizontal ground heat exchanger in Tunisia, Energy 61, 319-331 (2013)
25. ASHRAE A, Standard 55-2004 Thermal environmental conditions for human occupancy (American Society of Heating Refrigerating and Air-Conditioning Engineers Inc, Atlanta, 2004)

26. H. Zhang, L. Jiang, W. Zheng, S. You, T. Jiang, S. Shao, $\mathrm{X}$. Zhu, Experimental study on a novel thermal storage refrigerant-heated radiator coupled with air source heat pump heating system, Build. Environ. 164, 106341 (2019)

Cite this article as: Sabrin Korichi, Bachir Bouchekima, Nabiha Naili, Messaouda Azzouzi, The thermal behavior of a novel wall radiator panel coupled with horizontal ground source heat pump heating system: improve indoor environment to reduce the airborne transmission of infectious diseases, Renew. Energy Environ. Sustain. 5, 11 (2020) 